\title{
TECHNICAL STRATEGY FOR REVITALIZING URBAN RIVER WATER QUALITY THROUGH STRUCTURAL APPROACH AT NATIONAL UNIVERSITY OF MALAYSIA (UKM) BANGI CAMPUS, SELANGOR, MALAYSIA
}

\author{
MAHMUd, M. H. ${ }^{1}-$ LEE, K. E. ${ }^{1,2^{*}}-$ MOKHTAR, M. ${ }^{1}-$ WAHID, M. A. ${ }^{3}$ \\ ${ }^{1}$ Research Centre for Sustainability Science \& Governance (SGK), Institute for Environment \\ and Development (LESTARI), Universiti Kebangsaan Malaysia \\ 43600 UKM Bangi, Selangor, Malaysia \\ (phone: +603-8921-4144; fax: +603-8925-5104) \\ ${ }^{2}$ Center for Research and Instrumentation Management (CRIM), Universiti Kebangsaan \\ Malaysia, 43600 UKM Bangi, Selangor, Malaysia \\ (phone: +603-8921-3095; fax: +603-8925-4550) \\ ${ }^{3}$ Faculty of Civil Engineering, Universiti Teknologi MARA \\ 40450 Shah Alam, Selangor, Malaysia \\ (phone: +603-5544-3311; fax: +603-5543-5275) \\ *Corresponding author \\ e-mail: khaiernlee@ukm.edu.my \\ (Received 21 $1^{\text {st }}$ Dec 2017; accepted $1^{\text {st }}$ May 2018)
}

\begin{abstract}
This paper aims to provide technical insights on revitalizing urban river water quality through structural approach in Alur Ilmu urban river, National University of Malaysia @ Universiti Kebangsaan Malaysia (UKM) Bangi Campus. The structural approach consists of three main parts: site profiling, water quality assessment to determine spatial distribution of pollutions and on-site water treatment system. The selected water quality parameters were Dissolved Oxygen, Ammoniacal Nitrogen, $\mathrm{pH}$, Total Suspended Solid, Chemical Oxygen Demand and Biological Oxygen Demand. The obtained values were indexed in accordance with Water Quality Index (WQI) of National Water Quality Standard (NWQS) for Malaysia and interpolated to produce thematic maps indicating the point sources of pollution using Kriging model. A series of on-site water treatment system, namely constructed wetland, gross pollutant trap, permeable pavement wall and floating treatment wetland were then strategically constructed using both information obtained from site profiling and spatial distribution. The structural approach has been deployed since 12 June 2015 and has shown significant improvement on average WQI for all thirteen stations from 68.85 to 79.87 in less than 10 months. The most influential point for source of pollution was detected at AL5 (FST Café), it has improved the most, from 51.36 to 73.18 . The structural approach has successfully improved Alur Ilmu water quality and should be complemented with non-structural approach to ensure the sustainability of water resource.
\end{abstract}

Keywords: site profiling, water quality assessment, spatial distribution, Kriging model, onsite treatment system

\section{Introduction}

Under circumstances of technology advancement, social change and economic development have given impetus to rapid urbanization and land expansion, pristine water quality and natural appealing urban river are apparent if we incorporate environmental consideration into our current practice and future planning. Good governance of urban river through integrated water resource management has tapped valuable potentials for many developed countries towards economic, social and environmental benefits. Cleaner urban river water contributes to alternative water 
resource, i.e. groundwater recharging and stormwater harvesting (Lim and Lu, 2016), fulfilling public demand for better environmental health (Environmental Protection Agency (EPA), 2016), enhancing their quality of life, and providing nature aesthetic appreciation and gentrification for safe, efficient and greener neighbourhood (Reese, 1991; Lim et al., 2013). Besides, it establishes a niche on revitalizing urban rivers through various methodologies and water treatment systems. However, the options available in adopting management and water treatment system have created ambiguity to decision makers and engineers to suit their local context. A flaw adoption of water treatment and management will exacerbate more than only urban river water problems. For example, poor understanding of the urban river water pollution dynamics from introduction of point and non-point sources of pollution (Curriero, 2007), resulting to unnecessary site's geomorphological change and selection of ineffective water treatment system. This creates more loss as more pollutants created from land change, financial strain from high maintenance of unsuitable water treatment system and discontentment from the public.

In revitalizing urban river, structural approach is one of the best management practices (BMP) to remove the pollutants from the water body (Lim and Lu, 2016; Thomas and Reese, 2003). The goal of BMP is to provide sufficient pollution reduction of mass inflow i.e. from point and non-point sources of pollution to meet the targeted mass outflow provided by local standards and guidelines (Thomas and Reese, 2003). Challenges of the structural approach in BMP are the complex urban rainfall-runoff contributing to various types of pollution, myriad of biological, chemical and pollution reactions in the water body. Moreover, despite with careful planning of constructed water treatment systems, the reduction of pollutions was inconsistent (Thomas and Reese, 2003; Brown and Clarke, 2007; Lim and Lu, 2016), therefore it is hard to achieve replicable results from previous case studies. Hence, structural approach is designed in a set of action plan using scientific analyses that optimise both aspects of the site features and the selected water treatment systems by mitigating the pollutions close to its source according to standards stipulated by local authorities or government. Similar to most of the developed countries, Malaysia government has outlined national water quality standard for inland water quality namely Water Quality Index (WQI) to identify and classify the level of acceptance of water quantity and quality for human use and environmental health (Natural Resources and Environment Malaysia (NRE), 2006). The WQI comprises of six water quality parameters, namely dissolve oxygen (DO), Ammoniacal Nitrogen $\left(\mathrm{NH}_{3}-\mathrm{N}\right)$, total suspended solid (TSS), chemical oxygen demand (COD) and biological oxygen demand (BOD), are calculated into a cumulative value of the 6 parameters in sub-indices with weightage that can be classified into five classes and usages. Table $1 a$ is National Water Quality Standard (NWQS) for Malaysia with limits for classes of pollutant concentration acceptance level of the subindices Malaysia's WQI (NRE, 2006). Table $1 b$ is DOE WQI Classification for Malaysia with limits for inland water quality (NRE, 2006). Table $1 c$ is the description list of the classes and its utilities that have been mentioned in Tables $1 a$ and $1 b$. Water with Class I in WQI indicates clean and is the most suitable for human consumption and usage. Increasing in WQI indicates the more polluted of urban river water quality is, which is harmful for human use and to the environment.

This paper aims to provide insights on the technical aspects of revitalizing urban river water quality through structural approach using site profiling, spatial distribution analysis of WQI and on-site treatment system. Therefore, the current research enables 
decision makers and engineers to target and apply treatment to remove pollutants in the water body as close as possible to the source of pollution based on the case study in Alur Ilmu, National University of Malaysia @ Universiti Kebangsaan Malaysia (UKM) Bangi Campus, Selangor, Malaysia.

\section{Methods}

\section{Study area}

Alur Ilmu is a $1.79 \mathrm{~km}$ urban river long stretching across the main campus of the National University of Malaysia (UKM), Bangi, Selangor, Malaysia before flowing into the Langat River. Figure $1 a$ is the location of National University of Malaysia (UKM), Bangi Campus, Selangor, Malaysia. Figure $1 b$ shows the location of the revitalization of water quality study through structural approach at first $500 \mathrm{~m}$ of Alur Ilmu urban river upstream, UKM Bangi, Selangor, Malaysia with sampling sites and the placement of the on-site water treatment system. The first $100 \mathrm{~m}$ of Alur Ilmu is located at the lowest elevation point of hilly terrain and flows with normal elevated terrain, closely surrounded by impervious area from building and impervious pavement. It receives water source from the Permanent Reserved Forest and Natural Education Forest (Hutan Simpan Kekal and Hutan Pendidikan Alam) UKM, rain water and stormwater runoff. Alur Ilmu has been reinforced from a natural river into a concreted urban river in 1970s concurrent with the construction of the first batch of UKM's faculty buildings without changing its original flow (Universiti Kebangsaan Malaysia (UKM), 1978). Alur Ilmu serves as an irrigation system to remove excess water from impervious area nearby the urban river and avoid flooding. Alur Ilmu is a model of an urban river as it receives clean forest water from the upstream and surrounded by the growth of technology, social and economic activities along the urban river which convergences into Langat River at the downstream. In this study, revitalization of Alur Ilmu water quality was conducted within the upstream (500 $\mathrm{m}$ length and $5 \mathrm{~m}$ width starting from Ghazali Lake to Silt Collection Tank). Average water depth is about $1.8 \mathrm{~m}$ with land coverage of $95 \%$ impervious area (Universiti Kebangsaan Malaysia (UKM), 1978). The average water velocity of the urban river is $0.1 \mathrm{~ms}^{-1}$ during dry season and increases to an average of 6 $\mathrm{ms}^{-1}$ during rain. In Figure $1 b$, the light blue colour indicates the area selected for spatial distribution analysis. The area was selected to identify point and non-point sources of pollutions in Alur Ilmu and eliminate complication of spatially interpolating within non-convex or irregularly shaped regions (Ghafouri and Swain, 2005). The WQI was reported depreciating from Class II (Chong, 1999) to Class III in 2003 (Mokhtar et al., 2005) to Class IV in 2012 (Din et al., 2012) and Class V in 2017 (Hafiyyan et al., 2017a).

\section{Structural approach}

Structural approach is a systematic action plan to understand a complex set of anthropogenic and natural physical, chemical and biological factors which act as pollution to the receiving water and provide effective hardware solution to remove pollutants in the receiving water. The main goal of the structural approach is to obtain optimum pollution reduction perpetuated throughout the years in compliance to management goals and local water quality standards. The approach consists of three components: 1) site profiling, 2) water quality assessment and 3) on-site water treatment 


$$
\text { - } 2684 \text { - }
$$

and should be sequenced as this order. Figure 2 depicts the research strategy for the structural approach in revitalizing urban river water.

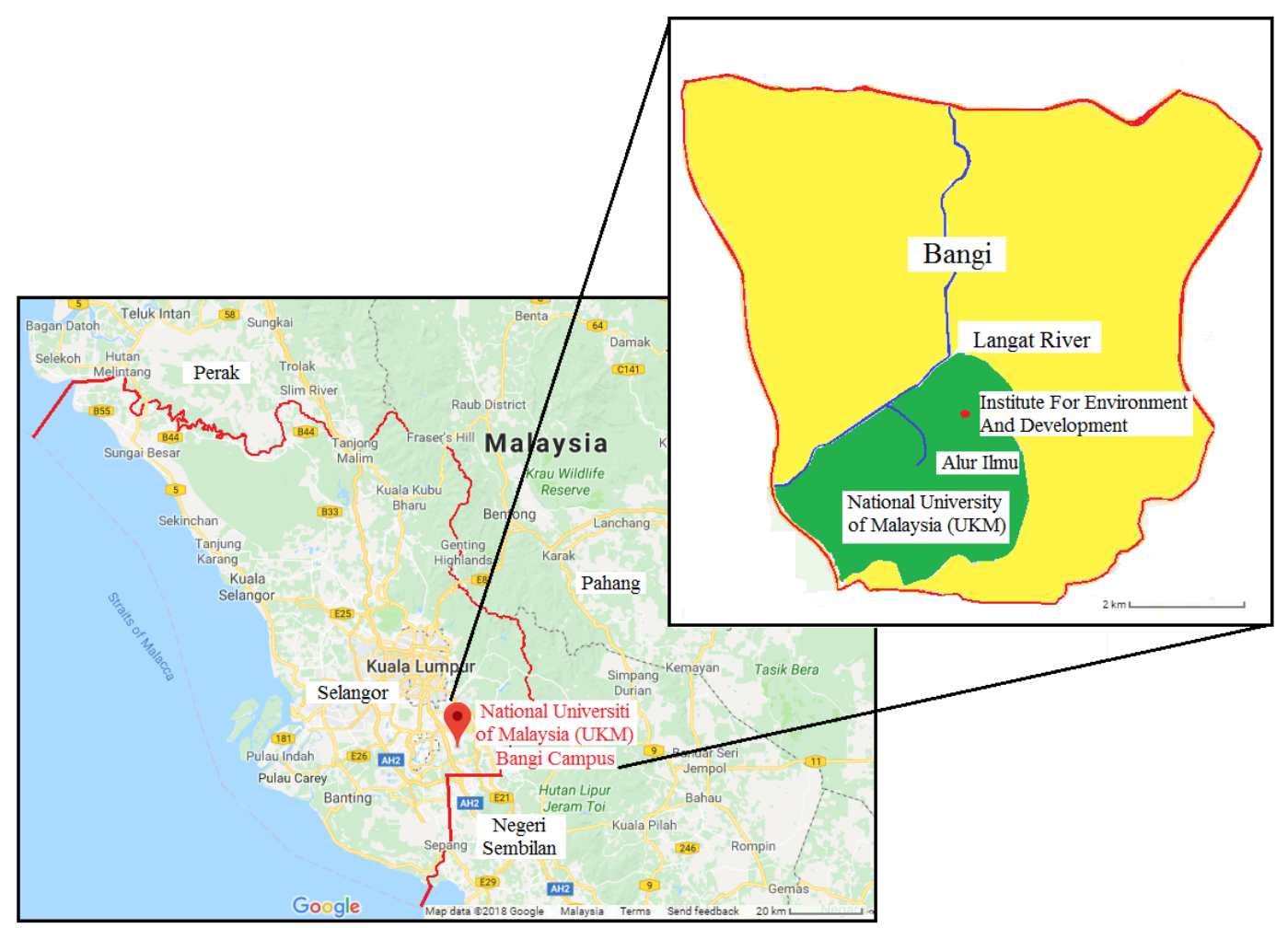

$\mathbf{a}$
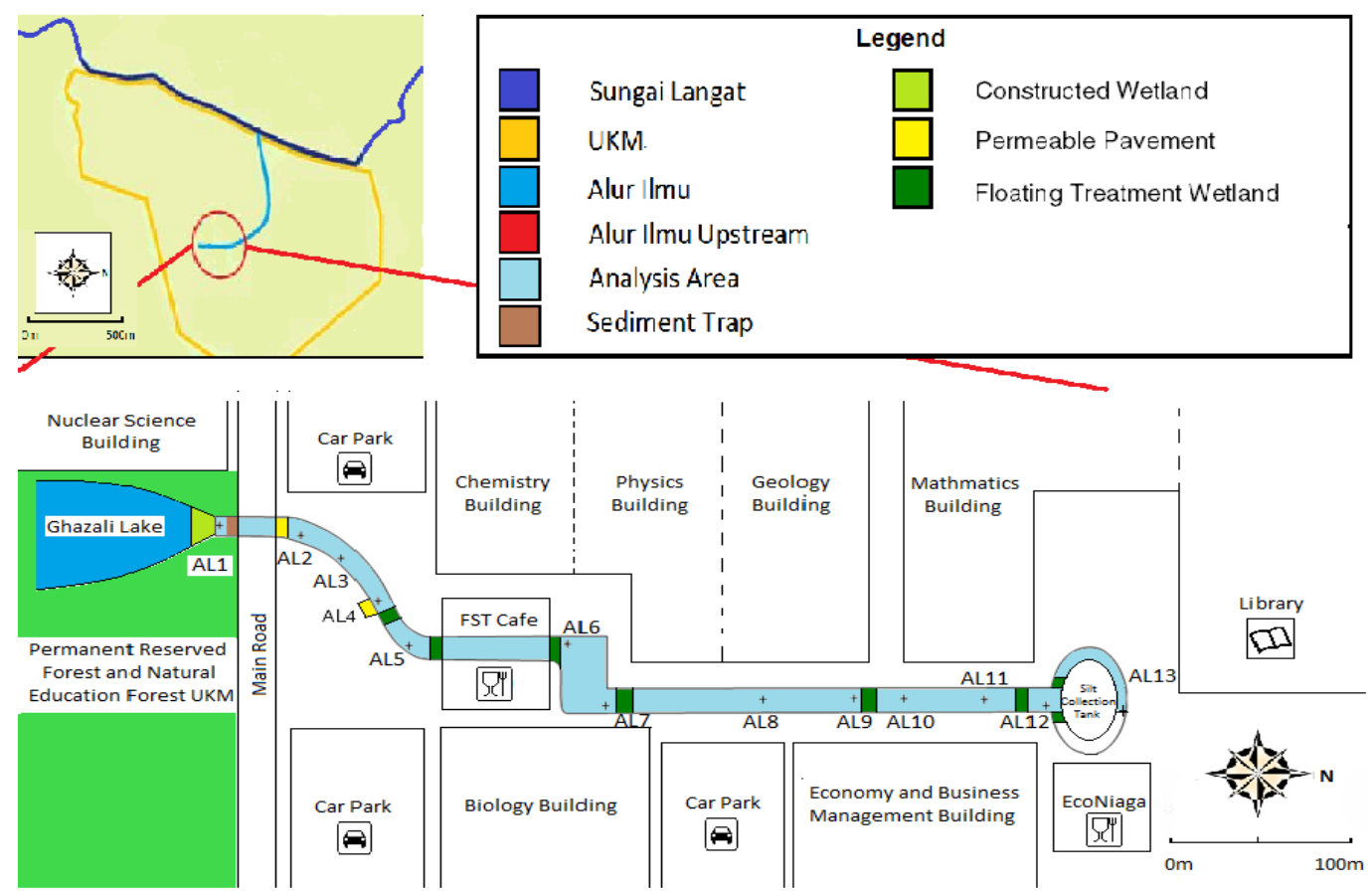

b

Figure 1. a Location of National University of Malaysia (UKM), Bangi Campus, Selangor, Malaysia. $\boldsymbol{b}$ Location of the revitalization of water quality study through structural approach at AlurIlmu urban river (500 m upstream), UKM Bangi, Selangor, Malaysia with sampling sites and the placement of the on-site water treatment system 


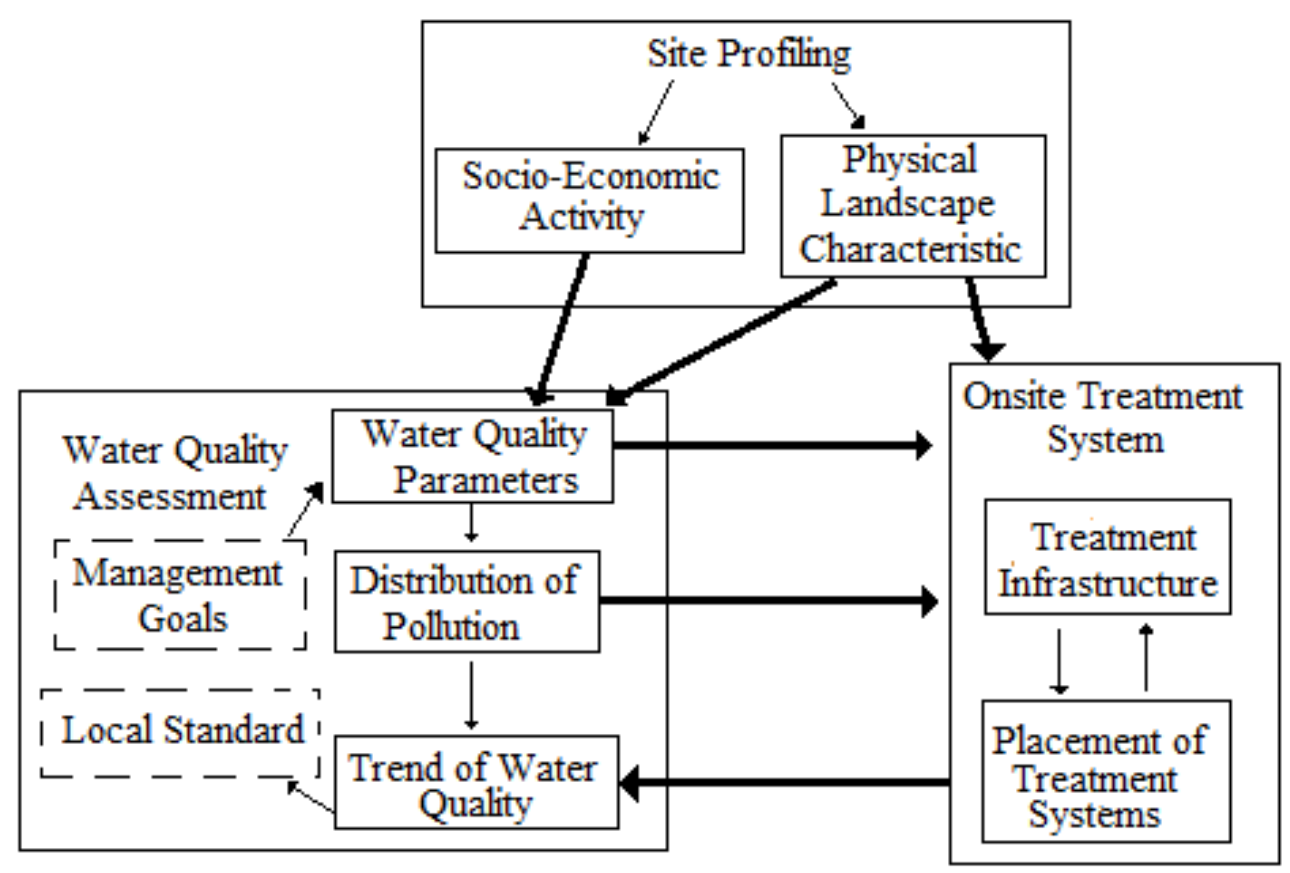

Figure 2. Research strategy for the structural approach and its components in urban river water revitalization

The first part of the approach is to develop a site profile of the study location comprises of its socio-economic activities and physical landscape characteristic along Alur Ilmu. Socio-economic activities refer to any human activities that occur nearby the urban river that can influence its water quality through point and non-point sources of pollutions. The physical landscape characteristic encompasses an outline of the urban river and its surrounding location including its geomorphological of the terrain, physical characteristic of the urban river and flow pattern of the urban river. The geomorphology of the terrain encompasses the slopes and nearby land use. Physical characteristic of the urban river is the distinctive feature or quality that describes the urban river and flow pattern is the water depth and water velocity of the urban river. Information of socioeconomic activities and physical landscape characteristic are instrumental for identification of the type and cause of pollution.

The second part of the structural approach is water quality assessment of Alur Ilmu. The assessment is conducted by underpinning three aspects which are water quality parameters, distribution of pollution and trend of its water quality. The water quality parameters refer to the physical, chemical and biological characteristic of the water (Water Environment Partnership in Asia (WEPA, 2017) that to be complied with management goals and local standards to protect the end user including human, animals, and ecosystem health or industrial and agriculture activities (Environmental Protection Agency (EPA), Ireland 2001). The water quality assessment for Alur Ilmu was conducted through in-situ monitoring and ex-situ analysis in accordance with National Water Quality Standards for Malaysia, namely Malaysia's WQI (Department of Environment Malaysia (DOE), 2007). Malaysia's WQI is a mathematical value from comprehensive calculation of selected water quality parameters namely dissolved oxygen (DO), $\mathrm{pH}$, Ammoniacal Nitrogen $\left(\mathrm{NH}_{3}-\mathrm{N}\right)$, total suspended solid (TSS), biological oxygen demand (BOD) and chemical oxygen demand (COD). The purpose of 
the index is to benchmark the water quality of surface water in Malaysia to the public about its uses (American Public Health Association (APHA), 2005). The obtained WQI is used to determine the distribution of pollution through spatial distribution analysis to produce a thematic map determining the distribution of point and non-point sources of pollution entering Alur Ilmu water body.

The selection of on-site water treatment system is based on two aspects, 1) the treatment infrastructure which includes its water treatment application, design criteria, specification, operation and maintenance and 2) the placement of the treatment system. The data obtained from site profiling and water quality assessment are rudimentary for the selection of the on-site treatment system.

\section{Sampling and analytical method}

Thirteen stations were selected based on inlets identified along first $500 \mathrm{~m}$ of Alur Ilmu and their GPS coordinates were recorded using Garmin Etrex 20 for spatial distribution analysis. Six water parameters were selected for in-situ monitoring and exsitu analysis for the water quality assessment, based on the National Water Quality Standards for Malaysia (Department of Environment Malaysia (DOE), 2007). The parameter were dissolved oxygen (DO), $\mathrm{pH}$, and Ammoniacal Nitrogen $\left(\mathrm{NH}_{3}-\mathrm{N}\right)$ for insitu monitoring and total suspended solid (TSS), biological oxygen demand (BOD) and chemical oxygen demand (COD) for ex-situ analysis. The in-situ monitoring for DO (\% saturation), $\mathrm{pH}$ (value) and $\mathrm{NH}_{3}-\mathrm{N}(\mathrm{mg} / \mathrm{L})$ were measured using YSI Multiparameter Sonde during mid-day (11 am $-1 \mathrm{pm})$ and water samples were collected for analysis. For ex-situ analysis, TSS (mg/L) was sampled using polyvinyl bottle and measured using gravimeter method Method 208D (American Public Health Association (APHA) (2005). BOD (value) was analysed by $\mathrm{BOD}_{5}$ Method by incubating the water samples for 5 days under temperature of $20{ }^{\circ} \mathrm{C}$ in an incubator and analysed using YSI EcoSense Self-stirring BOD Probe. Differences between $\mathrm{DO}_{\text {first }}$ and $\mathrm{DO}_{\text {final }}$ were recorded for BOD net value (American Public Health Association (APHA), 2005). COD parameter was carried out using 5220B chemical oxygen demand, closed reflux, titrimetric method and was analysed using HACH Spectrophotometer DR3900 Laboratory VIS Spectrophotometer with RFID* Technology (American Public Health Association (APHA), 2005). The six water quality parameters for each station in Alur Ilmu were used to calculate WQI value using WQI formula and calculation in Equation 1. The obtained WQI of each station was compared with DOE WQI Classification in Malaysia and uses (NRE, 2006) in Tables $1 a$ and $l b$ for water pollution classification and limits. The six parameters: $\mathrm{DO}, \mathrm{pH}, \mathrm{NH}_{3}-\mathrm{N}, \mathrm{TSS}, \mathrm{BOD}$ and $\mathrm{COD}$ are the water quality parameters approved by the Malaysia's DOE for evaluation $(E q .1)$ of overall status of surface water including urban river water. From Equation 1, DO carries the maximum weightage of $22 \%$ and $\mathrm{pH}$ carries the minimum of $12 \%$ in the WQI equation. The WQI equation constitutes of sub-indices of the six water quality parameters calculated according to the best-fit relations given in Equations 2 to 7 . Variation of the sub-indices with concentrations of the respective pollutants are depicted in Figure 3. Better quality of the water represented by high value of the index (Mamun and Zainudin, 2013).

$$
\begin{aligned}
\mathrm{WQI} & =(0.22 * \mathrm{SIDO})+(0.19 * \mathrm{SIBOD})+(0.16 * \mathrm{SICOD}) \\
& +(0.15 * \mathrm{SIAN})+(0.16 * \mathrm{SISS})+(0.12 * \mathrm{SipH})
\end{aligned}
$$




$\begin{array}{ll}\text { SIDO } & =\text { Subindex DO }(\% \text { saturation }) \\ \text { SIBOD } & =\text { Subindex BOD } \\ \text { SICOD } & =\text { Subindex COD } \\ \text { SIAN } & =\text { Subindex NH3-N } \\ \text { SISS } & =\text { Subindex SS } \\ \text { SipH } & =\text { Subindex pH }\end{array}$

Subindex for DO (In \% saturation)

$$
\begin{array}{ll}
\text { SIDO }=0 & \text { for } x \leq 8 \\
\text { SIDO }=100 & \text { for } x \leq 92 \\
\text { SIDO }=-0.395+0.030 x^{2}-0.00020 x^{3} & \text { for } 8<x<92
\end{array}
$$

Subindex for BOD

$$
\begin{aligned}
& \text { SIBOD }=100.4-4.23 \mathrm{X} \quad \text { for } \mathrm{x} \leq 5 \\
& \text { SIBOD }=108 * \exp (-0.055 \mathrm{x})-0.1 \mathrm{x} \quad \text { for } \mathrm{x}>5
\end{aligned}
$$

Subindex for COD

$$
\begin{array}{ll}
\text { SICOD }=-1.33 X+99.1 & \text { for } x \leq 20 \\
\text { SICOD }=103 * \exp (-0.0157 x)-0.04 x & \text { for } x>20
\end{array}
$$

Subindex for NH3-N

$$
\begin{array}{ll}
\text { SIAN }=100.5-105 \mathrm{x} & \text { for } \mathrm{x} \leq 0.3 \\
\text { SIAN }=94 * \exp (-0.573 \mathrm{x})-5 * \mathrm{I} \text { x 2 I } & \text { for } 0.3<\mathrm{x}<4 \\
\text { SIAN }=0 &
\end{array}
$$

Subindex for SS

$$
\begin{array}{ll}
\text { SISS }=97.5 * \exp (-0.00676 \mathrm{x})+0.05 \mathrm{x} & \text { for } \mathrm{x} \leq 100 \\
\mathrm{SISS}=71 * \exp (-0.0061 \mathrm{x})+0.015 \mathrm{x} & \text { for } 100<\mathrm{x}<1000 \quad \text { (Eq.6) } \\
\text { SISS }=0 & \text { for } \mathrm{x} \geq 1000
\end{array}
$$

Subindex for $\mathrm{pH}$

$$
\begin{aligned}
& \text { SIpH }=17.02-17.2 x+5.02 x^{2} \\
& \text { SIpH }=-242+95.5 x-6.67 x^{2} \\
& \text { SIpH }=-181+82.4 x-6.05 x^{2} \\
& \text { SIpH }=536-77.0 x+2.76 x
\end{aligned}
$$

for $\mathrm{x}<5.5$

for $5.5 \leq \mathrm{x}<7$

for $7 \leq \mathrm{x}<8.75$

for $\mathrm{x} \geq 8.75$

\footnotetext{
* means multiply with
} 


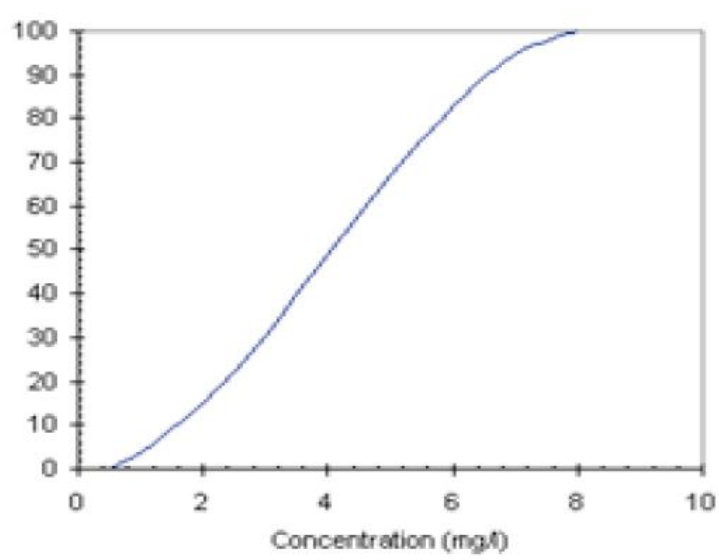

(a) Dissolved Oxygen (DO)

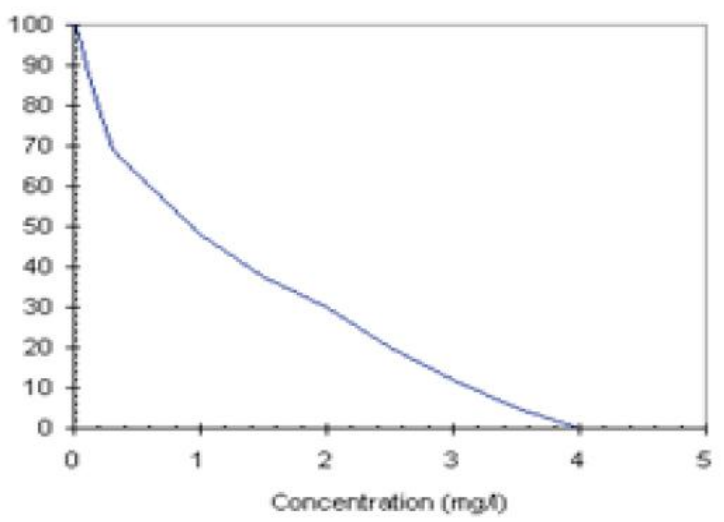

(d) Ammoniacal Nitrogen $\left(\mathrm{NH}_{3}-\mathrm{N}\right)$

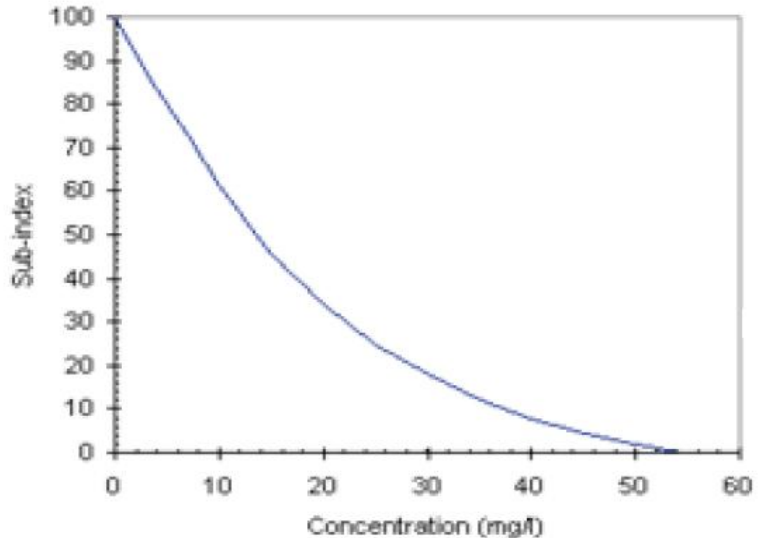

(b) Biochemical Oxygen Demand (BOD)

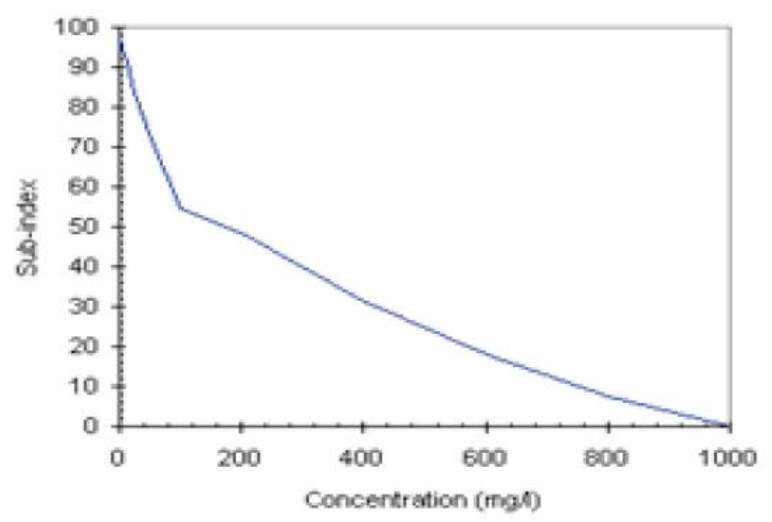

(e) Suspended Solids (SS)

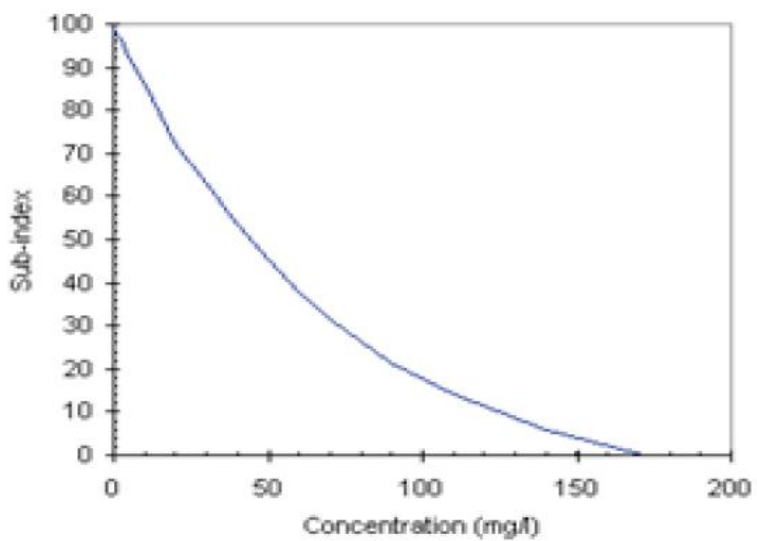

(c) Chemical Oxygen Demand(COD)

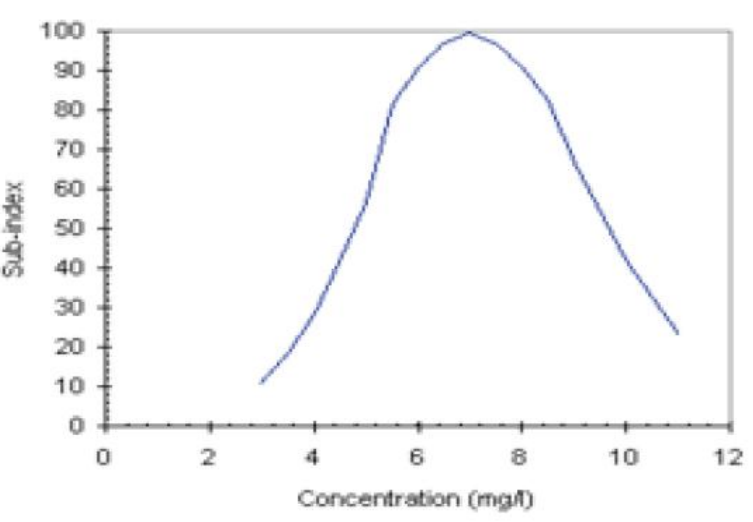

(f) $\mathrm{pH}$

Figure 3. Variation of sub-indices with pollutant concentrations for the parameters required to determine Malaysia's WQI (Mamun and Zainudin, 2013) 
Table 1a. Malaysia's Interim of National Water Quality Standard (NWQS) with limit for classes (NRE, 2006)

\begin{tabular}{c|c|c|c|c|c|c}
\hline \multirow{2}{*}{ Parameters } & \multirow{2}{*}{ Unit } & \multicolumn{5}{|c}{ Limits for Classes } \\
\cline { 3 - 7 } & & I & II & III & IV & V \\
\hline $\mathrm{DO}$ & $\mathrm{mg} / \mathrm{l}$ & $>7.0$ & $5.0-7.0$ & $3.0-5.0$ & $1.0-3.0$ & $<1.0$ \\
$\mathrm{pH}$ & - & $>7.0$ & $6.0-7.0$ & $5.0-6.0$ & $<5.0$ & $<5.0$ \\
$\mathrm{NH}_{3}-\mathrm{N}$ & $\mathrm{mg} / \mathrm{l}$ & $<0.1$ & $0.1-0.3$ & $0.3-0.9$ & $0.9-2.7$ & $>2.7$ \\
$\mathrm{TSS}$ & $\mathrm{mg} / \mathrm{l}$ & $<2.5$ & $25-50$ & $50-150$ & $50-300$ & $>300$ \\
$\mathrm{BOD}$ & $\mathrm{mg} / \mathrm{l}$ & $<1$ & $1-3$ & $3-6$ & $6-12$ & $>12$ \\
$\mathrm{COD}$ & $\mathrm{mg} / \mathrm{l}$ & $<10$ & $10-25$ & $25-50$ & $50-100$ & $>100$ \\
\hline
\end{tabular}

Table 1b. Malaysia's WQI classification with limits (NRE, 2006)

\begin{tabular}{c|c|c|c|c|c}
\hline \multirow{2}{*}{} & \multicolumn{5}{|c}{ Limits for Classes } \\
\cline { 2 - 6 } & I & II & III & IV & V \\
\hline \multirow{2}{*}{ WQI } & $<92.7$ & $76.5-92.7$ & $51.9-76.5$ & $31.0-51.9$ & $>31.0$ \\
\hline \multirow{2}{*}{ Pollution level } & \multicolumn{2}{|c|}{ Clean } & $\begin{array}{c}\text { Slightly polluted } \\
80-60\end{array}$ & $\begin{array}{c}\text { Polluted } \\
0-59\end{array}$ \\
\hline
\end{tabular}

Table 1c. Malaysia's WQI classification (NRE, 2006)

\begin{tabular}{c|c}
\hline CLASS & USES \\
\hline Class I & Conservation of natural environment \\
& Water Supply I - Practically no treatment necessary \\
Fishery I - Very sensitive aquatic species
\end{tabular}

\section{Data acquisition and statistical analysis}

WQI before treatment was obtained in June 2015 and WQI after treatment was taken in October 2016 to March 2017. The WQI for the thirteen stations were interpolated to produce thematic maps of spatial distribution of pollution using Kriging model via Surfer ${ }^{\circledR} 11$ for water quality modelling. Kriging model was chosen in this study because it is the most accurate model to present interpolation of water quality data for liquid flowing in a conduit that does not completely enclose the liquid, i.e. concreted stream and river (Ghafouri and Swain, 2005). Kriging is a geostatistical gridding method which expresses trend within the source of data. For example, alternatively of forming isolated peaks at the similar location on the map, it allows the peaks to connect and form as a ridge (Golden Software, 2017). Below is the general linear regression model for Kriging map interpolation $(E q .8)$, showing how WQI value treated via interpolation (predicted) for notation purposes. From the equation, $s$ is denoted as a 
generic spatial location that continuously contrasts over some domain of interest. $\mathrm{Y}(s)$ is the result of interest from the interpolation value of non-sample WQI data at $s$.

$$
\widehat{\mathrm{Y}}(s)=\beta_{0}+\beta_{1} \mathrm{X}_{1}+\varepsilon(\mathrm{s})
$$

$\mathrm{X}_{1}(s)$ expresses a potential covariate indexed by location $s$ which may have more than one covariates. $\beta_{1}$ is the covariate's associated regression effect while $\beta_{0}$ is the constant term and $\varepsilon(\mathrm{s})$ is error term. The uncertainty within the universal regression approach is modelled with the random error term $\varepsilon(\mathrm{s})$, assumed to have zero means, constant variance and a multivariate correlation structure to accommodate spatial dependence (Murphy et al., 2010). The current study focuses on WQM-generated concentration of the WQI obtained. Using Kriging gridding method, WQI can be generated for all locations within the area, representing as the covariate $\left[\mathrm{X}_{1}(s)\right]$. The expected value of a parameter (i.e. $\beta_{0}+\beta_{1}$ [Modelled $\left.\mathrm{WQI}(s)\right]$ ) is different by location and is a function of the WQM-generated concentration. Residual error term is accounted for expected value which deviates in value and varies spatially. Thus, the Kriging gridding method reduces the concern regarding station in a flowing water body by accounting for a spatial varying expected value.

\section{On-site water treatment system}

The selection of on-site water treatment system undergoes screening of two general aspects which are treatment infrastructure and placement of treatment system. Both of the aspects should be complemented with the information gathered from site profiling and water quality assessment. Four components were considered in the treatment infrastructure, namely removal efficiency, design criteria, water treatment specification as well as operational and maintenance. Removal efficiency is the ability of water treatment to address targeted water quality parameters in the water body. Design criteria are the installation and development of the water treatment for on-site operation including the size and mechanism involved. Water treatment specification is the requirement for optimal efficiency and better performance and water treatment management suitability (Lim and Lu, 2016; Thomas and Reese, 2003; Din et al., 2012; Murphy et al., 2010). For the placement of the treatment system, two components are deliberated namely space limitation and strategic target close to the source of pollution.

From the aforementioned criteria, the selected on-site water treatment systems were constructed wetland, permeable pavement wall and floating treatment wetland. Figure 4 depicts the selected on-site water treatment systems used to revitalize Alur Ilmu water quality. All of the water treatment systems were fully deployed to Alur Ilmu on January 2016. The three water treatment systems were opted to complement Alur Ilmu's site profile through which Alur Ilmu is located close to human development and economic activities, i.e. faculty infrastructures, cafe and tarred road, hence the water quality is susceptible to water pollution. Surrounded by impervious hilly terrain, the concreted urban river received large surface runoff during rain. The constructed wetland was placed at the upstream of Alur Ilmu as it is effective to sink suspended solids using Bent Flag Alligator (Thalia geniculate). Permeable pavement wall and floating treatment wetland were selected because of flexible design criteria which can be retrofitted into the minimum available space of Alur Ilmu and effective on domestic water pollution and surface runoff. Four free-floating plants were studied to remove $\mathrm{NH}_{3}-\mathrm{N}$, TSS, and BOD concentration in the water sample. 

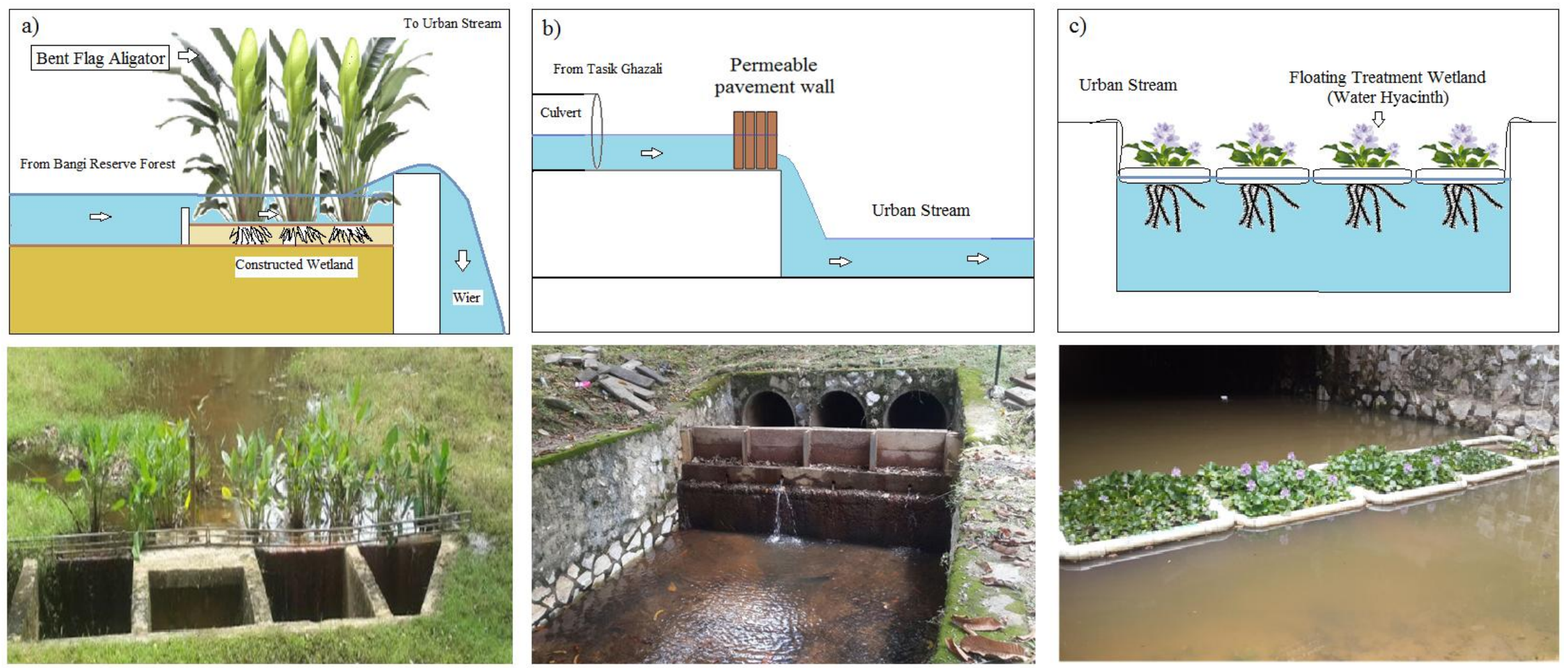

Figure 4. Schematic diagram of the on-site water treatment systems: CONSTRUCTED wetland (a), permeable pavement wall (b) and floating treatment wetland $(c)$ 
In order to determine the most effective free-floating plants to remove pollutions from the urban river water, four free-floating plants were selected for feasibility of phytoremediation in pollution removal of Alur Ilmu water sample. The selected freefloating plants are water hyacinth, Eichhornia crassipes (Mart.) Solms, water lettuce, Pistia stratiotes. L., rose water lettuce, Pistia sp. L. and pennywort, Centella asiatica, (L.) Urb. Base on the study, Water Hyacinth was chosen to be planted on top of the floating treatment wetland (coverage area $\sim 40 \mathrm{~m}^{2}$ ) because its effectiveness in removing urban storm water pollution and resilient to urban water dynamic (Hafiyyan et al., 2017b; Wang et al., 2013).

\section{Results}

Table 2 shows the inventory of the site profile of Alur Ilmu by which the urban river is bounded with infrastructures and has limited space for large on-site treatment system, namely swale, infiltration basin and wetland.

Table 2. Site profiling of Alur Ilmu urban river's socio economics activities and physical landscape characteristic

\begin{tabular}{|c|c|c|}
\hline \multicolumn{3}{|r|}{ Site Profile } \\
\hline $\begin{array}{l}\text { Socio-economic } \\
\text { activities }\end{array}$ & $\begin{array}{l}\text { - University setti } \\
\text { - Two Cafeteria }\end{array}$ & $\begin{array}{l}\text { ing (public) (UKM, 1978; UKM, 2013) } \\
\text { s (Economic activities) (UKM, 2013) }\end{array}$ \\
\hline \multirow{3}{*}{$\begin{array}{l}\text { Physical landscape } \\
\text { characteristic }\end{array}$} & $\begin{array}{c}\text { Geomorphological } \\
\text { of the terrain }\end{array}$ & $\begin{array}{l}\text { - } \quad \text { Hilly terrain (UKM, 2013) } \\
\text { - } \quad 95 \% \text { paved area (UKM, 2013) } \\
\end{array}$ \\
\hline & $\begin{array}{l}\text { Physical } \\
\text { characteristic of } \\
\text { the urban river }\end{array}$ & $\begin{array}{l}\text { - } 500 \mathrm{~m} \text { study area (from from Ghazali Lake to Silt } \\
\text { Collection Tank) } \\
\text { - Concreted urban river (from a natural river into a } \\
\text { concreted urban river) (UKM, 1978) } \\
\text { - No change of its original flow } \\
\text { - Bounded with paved area (Building and infrastructures) } \\
\text { (UKM, 1978; UKM, 2013) } \\
\text { - First } 100 \mathrm{~m} \text { of Alur Ilmu is located at the lowest elevation } \\
\text { point of hilly terrain and flows with normal elevated } \\
\text { terrain }\end{array}$ \\
\hline & $\begin{array}{l}\text { Flow pattern of } \\
\text { the urban river }\end{array}$ & $\begin{array}{l}\text { - Receives water source from the Permanent Reserved } \\
\text { Forest and Natural Education Forest, rain water and } \\
\text { stormwater runoff (Hafiyyan et al., 2017a) } \\
\text { - Average water depth is about } 1.8 \mathrm{~m} \\
\text { - average water velocity is } 0.1 \mathrm{~ms}^{-1} \text { during dry season } \\
\text { - average water velocity of } 6 \mathrm{~ms}^{-1} \text { during rainy season }\end{array}$ \\
\hline
\end{tabular}

The options available are to exercise major remodelling of Alur Ilmu which may harm the integrity of infrastructures in the vicinity or use Low Impact Development (LID) (Thomas and Reese, 2003) by retrofitting on-site water treatment system to the urban river. Based on Figure 4, the first part of Alur Ilmu being AL1 is suitable to use constructed wetland as it is the only large area available for effective filtration and detention of soil, sediment and large solids, i.e. plastics, dead branches and debris. The area was planted with Bent Flag Alligator (Thalia geniculate) and has the predominant removal mechanism for detention system. It enables to hold water for a period of time, 
allowing for settling of solid pollutants, filtration through vegetation, biological and chemical transformation, i.e. bioabsorptions (Thomas and Reese, 2003).As AL2 to AL13 have limited space for large on-site treatment system, the main culvert was built with permeable pavement wall. In addition, it is a retrofitted stormwater filtration system engineered to physically reduce the concentration of suspended solids, soil and silt by filtering the water vertically past through the porous medium (Thomas and Reese, 2003). Alur Ilmu water body is susceptible to myriad of pollutions from discharged points and surface runoff. Floating treatment wetland (FTW) plots were chosen and deployed into Alur Ilmu. During and after the installation of FTW, no change in any physical landscape characteristic was made because the plots were retrofitted into the urban river hence it is ideal to limited space urban setting. Previous study in 2017 has revealed the feasibility of phytoremediation in pollution removal of Alur Ilmu water sample (Hafiyyan et al., 2017b). Four free-floating plants were studied to remove $\mathrm{NH}_{3}-\mathrm{N}$, TSS, and BOD concentration in the water sample. The free-floating plants were water hyacinth, Eichhornia crassipes (Mart.) Solms, water lettuce, Pistia stratiotes. L., rose water lettuce, Pistia sp. L. and pennywort, Centella asiatica, (L.) Urb. The result showed rose water lettuce has the highest concentration reduction followed by water lettuce, water hyacinth and pennywort. However, among all four plants, water hyacinth was the most adaptable plants thus make it a better option for onsite phytoremediation of Alur Ilmu water. Water hyacinth (Eichhornia crassipes) was used for floating treatment wetland as regional stowmwater control (Hafiyyan et al., 2017b) The regional stormwater control is defined as facilities designed to manage stormwater runoff from multiple inlets for on-site control (Thomas and Reese, 2003; Martin et al., 2007). The floating treatment wetland designed for the regional stormwater control can maximize the utilization of developable land, to reduce operation and maintenance cost, retrofit potential and highly visible for enhancing natural aesthetical value. Hence, Water hyacinth was selected because of its effectiveness in large application of urban water body (Wang et al., 2013; Hafiyyan et al., 2017b). The thematic map in Figure 5 depicts the strategic design of the on-site treatment system layout at Alur Ilmu urban river and in thematic map of WQI improvement.

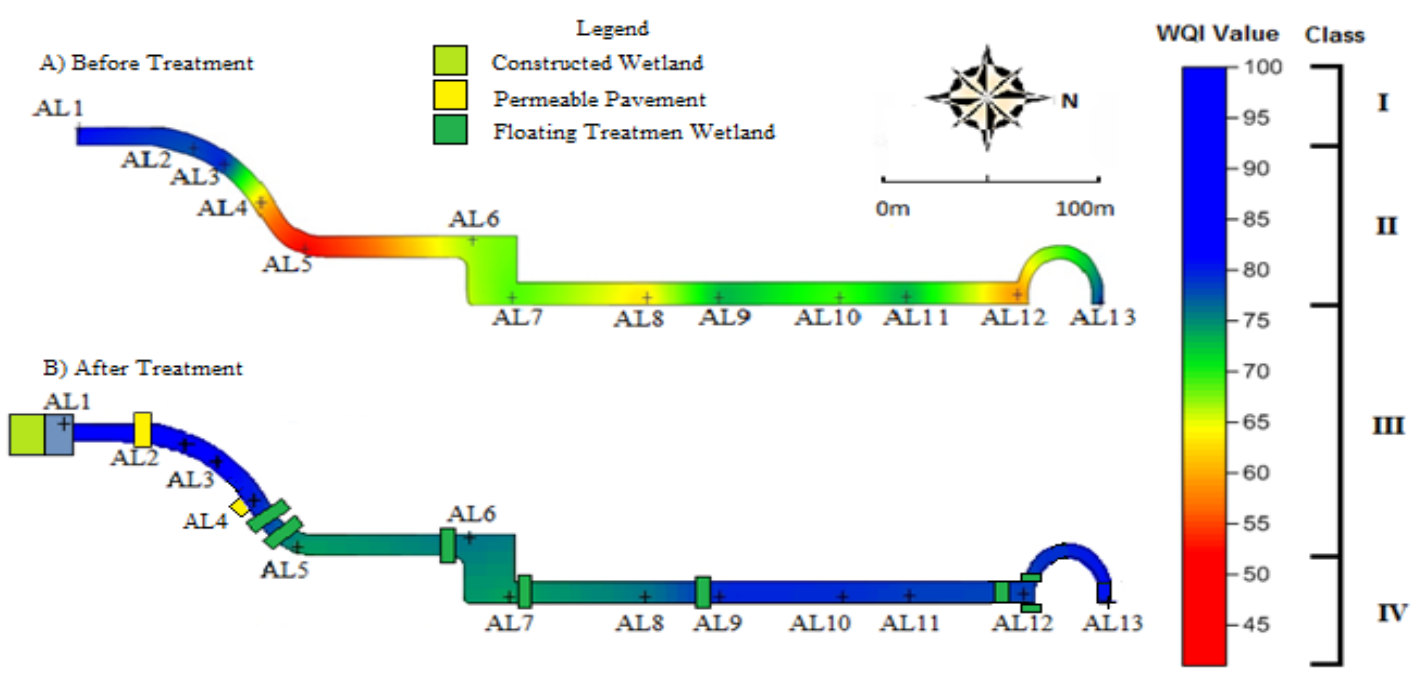

Figure 5. Comparison of spatial distribution of WQI in Alur Ilmu before and after the structural approach 
As shown in Table 3, the average WQI was 68.85 (Class III) in June 2015 (before treatment) and it has been improved to 79.87 (Class II) in October 2016 (after treatment) within 10 months with $16.00 \%$ of improvement in WQI. The highest average WQI after implemented structural approach was reported in Feb 2017 being 81.98 (Class II) with $19.07 \%$ of improvement in WQI. After implementing treatment, average WQI stabled at Class II ranging from 78.60 to 81.98 in WQI. The thematic maps show a general and clear pattern difference of WQI distribution before and after implementing the structural approach in Alur Ilmu. All the thirteen stations along $500 \mathrm{~m}$ of Alur Ilmu have generally improved spatially in WQI. The highest improvement of WQI was recorded at AL5 with $46.47 \%$ of improvement from 51.36 (Class IV, June 2015) to 75.23 (Class III, Feb 2017).

\section{Discussion}

Figure 5 shows that structural approach has a positive effect in revitalizing the urban river water quality. Figure 6 is a visual comparison of Alur Ilmu urban river before (top) and after (bottom) implementation of the structural approach. Based on Figure 5 and Figure 6, the structural approach has successfully improved both aesthetic and water quality of Alur Ilmu. The overall design of the structural approach is depending on the understanding of the complex pollution dynamic from natural phenomenon and anthropogenic factors of physical, chemical and biological forces emanating into the urban river (Thomas and Reese, 2003). Based on the aforementioned methodology, the water quality assessment and spatial distribution analysis are the tools used to understand pollution accumulation and urban hotspot (Thomas and Reese, 2003) of the land use prior to improve water quality of the urban river. Alur Ilmu is located at the lowest elevation level of hilly terrain, surrounded by imperious surface area and economic activities. Therefore, it is vulnerable to point and non-point sources of pollution.

The methodology of the current study followed the urban stromwater management manual for Malaysia (Manual Saliran Mesra Alam, MSMA) (Department of Irrigation and Drainage - DID, 2012), a guideline for non-point source of pollution control. The on-site treatment system used in the current study complied the key aspect of the manual which is to control pollution source using methods that produce the least impact towards the environment.

The thematic map before treatment is the superlative example to represent the pollution dynamic in the water body caused by point and non-point sources of pollution. The map indicates that pollutions accumulate at station AL5, AL8 and AL12. In relation to urban hotspot, AL5 and AL12 are both nearby to Cafeteria and AL8 is nearby to car park and faculty buildings. The introduction of pollution into the water body may come from the leakage of pipes and poor maintenance of pipes to channel waste produced into designated water treatment system and discarded properly through schedule waste disposal (Chong, 1999).

Wang et al. (2013) has shown positive results on revitalizing Lake Caohai $\left(10.5 \mathrm{~km}^{2}\right)$, China water quality which is bounded by urban infrastructure using onsite treatment system by deploying a large scale confined growth of Water hyacinth (coverage area $\left.4.3 \mathrm{~km}^{2}\right)$ on $\mathrm{N}$ removal $(761 \mathrm{t})(64 \%$ removal) within 6 months. The current study and Wang et al. (2013) were differ in water parameter tested because of different type of water pollutants were introduced into the water body respectively. Both of the studies used similar methodology to revitalize the water quality by profiling the study site and defining water quality parameters. 
Table 3. WQI of Alur Ilmu before and after treatment

\begin{tabular}{|c|c|c|c|c|c|c|c|c|c|c|c|c|c|c|c|c|c|c|c|c|c|c|c|}
\hline \multirow[b]{3}{*}{ Station } & \multirow{2}{*}{\multicolumn{2}{|c|}{ ocation of stations }} & \multirow{2}{*}{\multicolumn{3}{|c|}{$\begin{array}{c}\text { Before treatment } \\
\text { Jun } 2015 \\
\text { (hafiyyan et.al } \\
\text { 2017) }\end{array}$}} & \multicolumn{18}{|c|}{ After treatment } \\
\hline & & & & & & \multicolumn{3}{|c|}{ Oct 2016} & \multicolumn{3}{|c|}{ Nov 2016} & \multicolumn{3}{|c|}{ Dec 2016} & \multicolumn{3}{|c|}{ Jan 2017} & \multicolumn{3}{|c|}{ Feb 2017} & \multicolumn{3}{|c|}{ Mar 2017} \\
\hline & Long & Lat & WQI & Class & Status & WQI & Class & Status & WQI & Class & Status & WQI & Class & Status & WQI & Class & Status & WQI & Class & Status & WQI & Class & Status \\
\hline AL1 & 2.9219861 & 101.7817889 & 79.12 & II & S.P & 99.15 & I & $\mathrm{C}$ & 99.03 & I & $\mathrm{C}$ & 98.21 & I & $\mathrm{C}$ & 99.00 & I & $\mathrm{C}$ & 99.05 & I & $\mathrm{C}$ & 92.35 & I & $\mathrm{C}$ \\
\hline AL2 & 2.9227833 & 101.781675 & 76.34 & III & S.P & 90.40 & II & $\mathrm{C}$ & 90.61 & II & $\mathrm{C}$ & 92.11 & II & $\mathrm{C}$ & 90.11 & II & $\mathrm{C}$ & 92.90 & I & $\mathrm{C}$ & 90.43 & II & $\mathrm{C}$ \\
\hline AL3 & 2.9226806 & 101.7817306 & 78.12 & II & S.P & 80.81 & II & $\mathrm{C}$ & 81.43 & II & $\mathrm{C}$ & 82.51 & II & $\mathrm{C}$ & 80.68 & II & $\mathrm{C}$ & 81.20 & II & $\mathrm{C}$ & 81.01 & II & $\mathrm{C}$ \\
\hline AL4 & 2.92285 & 101.7817944 & 61.26 & III & S.P & 79.11 & II & S.P & 79.02 & II & S.P & 79.87 & II & S.P & 79.81 & II & S.P & 81.01 & II & $\mathrm{C}$ & 78.56 & II & S.P \\
\hline AL5 & 2.9230278 & 101.7818667 & 51.36 & IV & $\mathrm{P}$ & 73.18 & III & S.P & 71.24 & III & S.P & 71.53 & III & S.P & 72.91 & III & S.P & 75.23 & III & S.P & 70.11 & III & S.P \\
\hline AL6 & 2.9234722 & 101.7818139 & 66.23 & III & S.P & 75.13 & III & S.P & 75.36 & III & S.P & 75.65 & III & S.P & 75.05 & III & S.P & 78.23 & II & S.P & 73.02 & III & S.P \\
\hline AL7 & 2.923625 & 101.7819861 & 68.46 & III & S.P & 72.94 & III & S.P & 73.39 & III & S.P & 72.31 & III & S.P & 73.47 & III & S.P & 75.15 & II & S.P & 71.34 & III & S.P \\
\hline AL8 & 2.9239780 & 101.7819970 & 62.42 & III & S.P & 74.90 & III & S.P & 74.22 & III & S.P & 73.78 & III & S.P & 75.23 & III & S.P & 76.24 & III & S.P & 74.18 & III & S.P \\
\hline AL9 & 2.9242810 & 101.7820720 & 73.13 & III & S.P & 78.89 & II & S.P & 79.07 & II & S.P & 79.54 & II & S.P & 80.23 & II & $\mathrm{C}$ & 81.67 & II & $\mathrm{C}$ & 78.82 & II & S.P \\
\hline AL10 & 2.9245940 & 101.7821030 & 68.65 & III & S.P & 78.45 & II & S.P & 77.36 & II & S.P & 78.01 & II & S.P & 79.21 & II & S.P & 80.48 & II & $\mathrm{C}$ & 78.11 & II & S.P \\
\hline AL11 & 2.9248440 & 101.7820580 & 73.49 & III & S.P & 77.58 & II & S.P & 74.66 & III & S.P & 74.58 & III & S.P & 77.81 & II & S.P & 78.86 & II & S.P & 75.76 & II & S.P \\
\hline AL12 & 2.9250780 & 101.7820280 & 58.88 & III & $\mathrm{P}$ & 77.36 & II & S.P & 78.28 & II & S.P & 78.53 & II & S.P & 79.32 & II & S.P & 82.56 & II & $\mathrm{C}$ & 79.59 & II & S.P \\
\hline AL13 & 2.9251780 & 101.7819190 & 77.53 & II & S.P & 80.37 & II & $\mathrm{C}$ & 78.61 & II & S.P & 78.51 & II & S.P & 79.57 & II & S.P & 83.17 & II & $\mathrm{C}$ & 78.53 & II & S.P \\
\hline Average & - & - & 68.85 & III & S.P & 79.87 & II & S.P & 79.40 & II & S.P & 79.63 & II & S.P & 80.18 & II & $\mathrm{C}$ & 81.98 & II & $\mathrm{C}$ & 78.60 & II & S.P \\
\hline
\end{tabular}



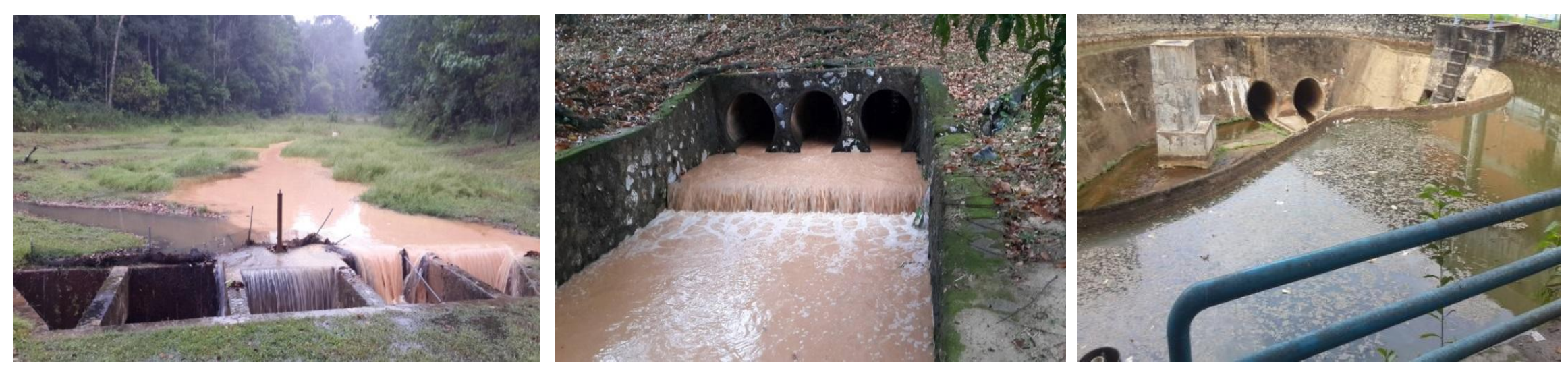

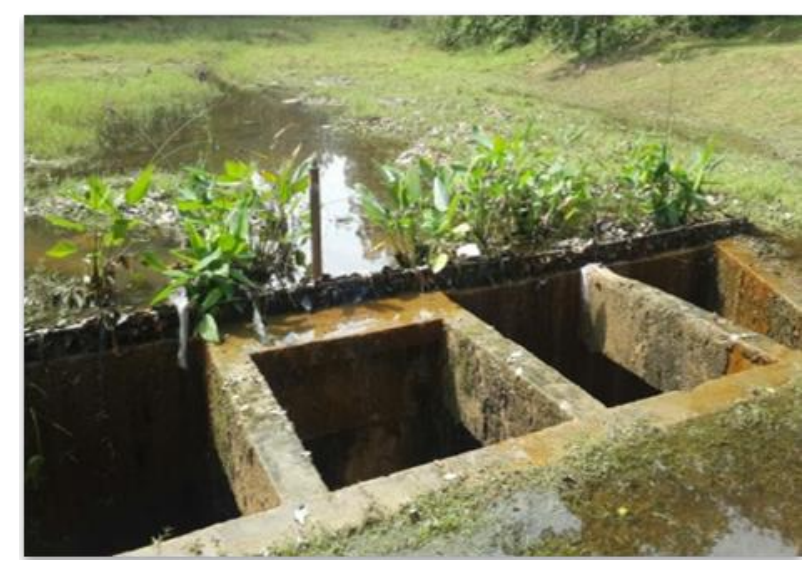

Constructed wetland + gross pollutant trap

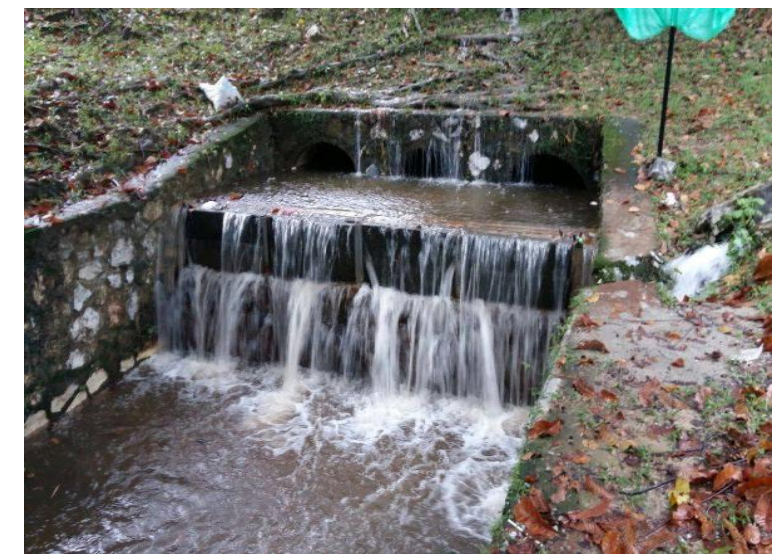

Permeable pavement wall

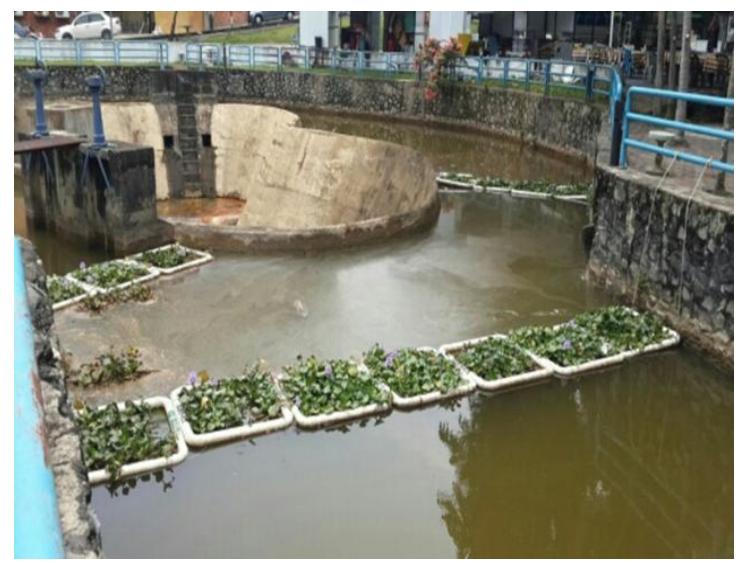

Floating treatment wetland

Figure 6. Pictures of Alur Ilmu urban river before (top) and after (bottom) implementation of the structural approach 
However, using spatial distribution analysis of water quality, the current study is able to determine optimal area for strategic placement of on-site treatment system needed that close to pollution source and using only approximate $1.6 \%$ of the study area to improve $16 \%$ of average WQI compared to Wang et al. (2013) that used $40.95 \%$ of the study area for $64 \%$ average $\mathrm{N}$ removal.

Figure 7 depicts WQI temporal trend of Alur Ilmu. The WQI trend projected that Alur Ilmu WQI will be more polluted if conventional management and practices are still continued. The intervention of structural approach has been proven able to bring back the water quality to Class II (Mokhtar et al 2005) after 10 months. Further improvement of the urban river WQI can be obtained if both structural and non-structural approaches are used through integrated management.

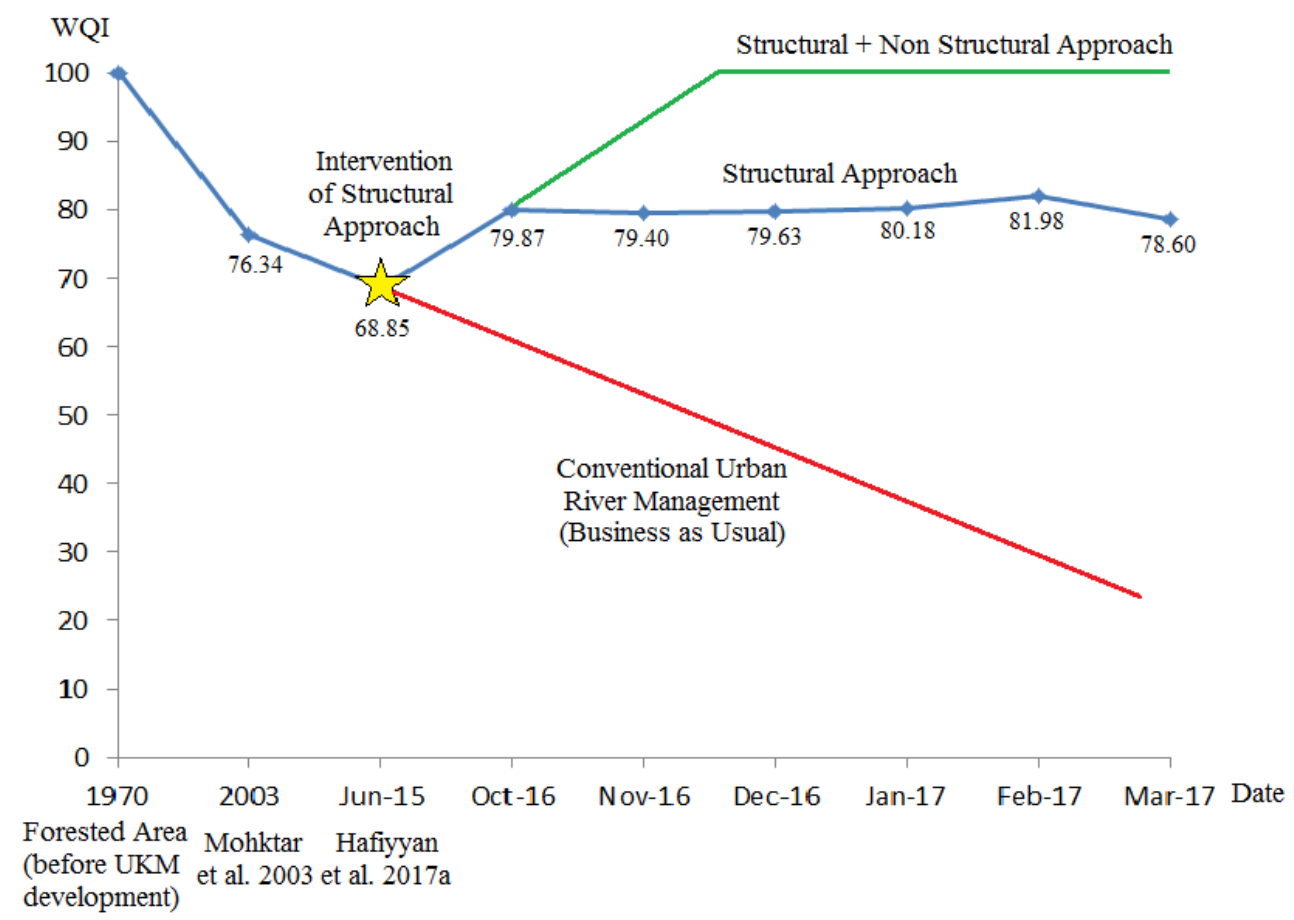

Figure 7. WQI temporal trend of Alur Ilmu

\section{Conclusion}

The result shows that the structural approach using constructed wetland, gross pollutant trap, permeable pavement wall and floating treatment wetland in revitalizing urban river's water quality have a positive effect to revitalize the water quality. The average WQI was 68.85 (Class III) in June 2015 (before treatment) and it has been improved to 79.87 (Class II) in October 2016 (after treatment) within 10 months with $16.00 \%$ of improvement in WQI. However, the structural approach should be complemented with a non-structural approach to control pollution before and after entering the urban river's water body as conventional infrastructure developments and economic activities with less consideration of environmental protection will cause various pollutions that can impair the capacity of the on-site treatment system. Realizing sustainable water resource management through revitalization urban river water quality, it is recommended to incorporate the urban river uses and functions into the urban masterplan that include environmental protection and gentrification as well as values for money. 
Acknowledgements. The authors would like to acknowledge the financial support for this study provided by Universiti Kebangsaan Malaysia through Dana Impak Perdana (DIP-2015-008) and Geran Universiti Penyelidikan (GUP-2017-016).

\section{REFERENCES}

[1] American Public Health Association (APHA) (2005): Standard Methods for the Examination of Water and Wastewater, $21^{\text {st }}$ ed. - American Public Health Association, Washington, D.C.

[2] Brown, R. R., Clarke, J. (2007): Transition to Water Sensitive Urban Design: The story of Melbourne, Report No. 07/1. - Facility for Advancing Water Biofiltration, Monash, Australia.

[3] Chong, W. L. (1999): Effluent Study of Oxidation Sewage Pond and Drainage System around National University of Malaysia (UKM) Campus. - National University of Malaysia, Bangi (in Malay).

[4] Curriero, F. C. (2007): On the use of non-Euclidean distance measures in geostatistics. Math Geol 38(8): 907-926.

[5] Department of Environment Malaysia (DOE) (2007): Malaysia Environmental Quality Report 2006. Chapter 3: River Water Quality. - Sasyaz Holdings Sdn Bhd, Kuala Lumpur, Malaysia.

[6] Department of Irrigation and Drainage (DID) (2012): Urban Stormwater Management Manual for Malaysia, $2^{\text {nd }}$ ed. - Government of Malaysia, Ministry of Agriculture, Malaysia.

[7] Din, H. M., Toriman, M. E., Mokhtar, M., Elfithri, R., Aziz, N. A. A., Abdullah, N. M., Kamarudin, M. K. A. (2012): Loading concentrations of pollutant in Alur Ilmu at UKM Bangi campus: Event mean concentration (EMC) approach. - The Malaysian Journal of Analytical Sciences 16: 353-365.

[8] Environmental Protection Agency (EPA) Ireland (2001): Parameters of Water Quality. Interpretation and Standards. - Environmental Protection Agency of Ireland, Wexford, Ireland.

[9] Ghafouri, M., Swain, C. E. (2005): Spatial analysis of urban stormwater quality. - Journal of Spatial Hydrology 5(1): 33-46.

[10] Golden Software (2017): A Basic Understanding of Surfer Gridding Methods. Part 1. https://support.goldensoftware.com/hc/en-us/articles/231348728-A-Basic-Understandingof- Surfer-Gridding-Methods-Part-1 (11 September 2017).

[11] Hafiyyan, M. M., Lee, K. E., Mokhtar, M., Marfiah, A. W., Goh, T. L., Norbert, S., Marlia, M. H., Azhar, A, H. (2017a): Spatial distribution of water quality index in stormwater channel: a case study of Alur Ilmu, UKM Bangi Campus. - Asia Pacific Environmental and Occupational Health Journal 3(1): 33-38.

[12] Hafiyyan, M. M., Lee, K. E., Goh, T. L. (2017b): On-site phytoremediation applicability assessment in Alur Ilmu, Universiti Kebangsaan Malaysia based on spatial and pollution removal analyses. - Environmental Science and Pollution Research 24: 22873-22884.

[13] Lim, H., Kim, J., Potter, C., Bae, W. (2013): Urban regeneration and gentrification: Land use impacts of the Cheonggye Stream Restoration Project on the Seoul's central business district. - Habitat International 39: 192-200.

[14] Lim, H. S., Lu, X. X. (2016): Sustainable urban stormwater management in the tropics: An evaluation of Singapore's ABC Waters Program. - Journal of Hydrology 538: 842862.

[15] Mamun, A. A., Zainudin, Z. (2013): Sustainable river water quality management in malaysia. - IIUM Engineering Journal 14(1): 29-42. 
[16] Martin, C., Ruperd, Y., Legret, M. (2007): Urban stormwater drainage management: The development of a multicriteria decision aid approach for best management practices. European Journal of Operational Research 181: 338-349.

[17] Murphy, R. R., Curriero, F. C., Ball, W. P. (2010): Comparison of spatial interpolation methods for water quality evaluation in the Chesapeake Bay. - Journal of Environmental Engineering @ ASCE 136(2): 160-171.

[18] Mokhtar, M., Chee, F. H., Chong, W. L, Ooi, Y. Y., Tan, B. H. (2005): Study of Alur Ilmu water quality in UKM: towards integrated water resource management approach. Malays J Analyt Sci 12(3): 388-395 (in Malay).

[19] Natural Resources and Environment Malaysia (NRE) (2006): Malaysia Environmental Quality Report 2006. Kuala Lumpur, KL. - Department of Environment Ministry of Natural Resources and Environment Malaysia, Kuala Lumpur.

[20] Reese, A. J. (1991): Successful Municipal Storm Water Management: Key Elements. Proceedings of the $15^{\text {th }}$ Annual Conference of the Association of Floodplain Managers, pp. 202-205. Denver, Colorado.

[21] Thomas, N. D., Reese, A. J. (2003): Municipal Stormwater Management. - Lewis Publisher, USA.

[22] United States Environmental Protection Agency (EPA) (2016): Achieving Water Quality through Integrated Municipal Stormwater and Wastewater Plans. https://www.epa.gov/sites/production/files/.../memointegrated municipalplans_0.pdf (1 November 2016).

[23] Universiti Kebangsaan Malaysia (UKM) (1978): National University of Malaysia Physical Development Report for 1977/78 Academic Session. ${ }^{\text {rd }}$ The Meeting Board on $29^{\text {th }}$ Jun 1978. - UKM, Bangi (in Malay).

[24] Universiti Kebangsaan Malaysia (UKM) (2013): National University of Malaysia Physical Development Report for UKM Bangi Campus 2007-2020. - UKM, Bangi.

[25] Wang, Z., Zhang, Z., Zhang, Y., Zhang, J., Yan, S., Guo, J. (2013): Nitrogen removal from Lake Caohai, a typical ultra-eutrophic lake in China with large scale confined growth of Eichhorniacrassipes. - Chemosphere 9(2): 177-183.

[26] Water Environment Partnership in Asia (WEPA) (2017): Water Standards of Partner Countries. - http://wepa-db.net/3rd/en/topic/waterstandard/index.html (31 March 2017). 